\title{
Squamous cell carcinoma of oral cavity: changing trends
}

\begin{abstract}
Objective: The aim of this study was to evaluate the incidence of squamous cell carcinoma in the oral cavity, its risk factors, site, and age of occurrence.

Material and methods: One hundred and nine cases of squamous cell carcinoma involving the oral cavity were retrieved from the records of Regional Cancer Centre, Benghazi and were analysed.

Results and conclusion: The age range was 11- 94 years with a male- female ratio 1.91. The tongue $(30.2 \%)$ was the most common site of occurrence. Tobacco was found as a risk factor in male patients above 40 years old, however, no risk factors were found in other patients. Due to the changing trends of cancer pattern and associated risk factors, we emphasize the need for an exhaustive evaluation to understand the biology and the role of

non conventional risk factors.
\end{abstract}

Keywords: oral cancer, etiology of oral cancer, risk factors
Volume 2 Issue 3 - 2015

\author{
Rafa El Gehani, Saravana HL Goteti \\ Department of Oral and Maxillofacial Surgery, University of \\ Benghazi, Libya
}

\begin{abstract}
Correspondence: Rafa El Gehani, Department of Oral and Maxillofacial Surgery, University of Benghazi, Faculty of Dentistry, Abdulnasser Street, PO Box 7099, Benghazi, Libya, Tel
\end{abstract} 002 18-92-31 I |641,Email ragehani@yahoo.com

Received: April 22, 2015 | Published: May 29, 2015
Abbreviations: OSCC, oral squamous cell cancer; SCC, squamous cell carcinoma; HPV, human papilloma virus

\section{Clinical implications}

An increase in the reports of oral squamous cell cancer (OSCC) in younger patients with no or minimal history of traditional risk factors is of a grave concern and more research needs to be done to identify and redefine the risk factors for education, prevention and diagnosis.

\section{Introduction}

Squamous cell carcinoma (SCC) comprises $85-90 \%$ of all malignancies involving oral cavity ${ }^{1}$ and is prevalent in young adults $(\leq 40 \mathrm{ye}-$ ars) and rare in paediatric subjects $(<20$ years $){ }^{2,3}$ Recent interest to understand the demographic distribution and pattern of SCC in young adults is being performed presently with little literature on SCC in paediatric patients. The occurrence of SCC in the adult population has been mainly attributed to major risk factors, such as tobacco, alcohol, and other etiologic factors such as drugs, viral infections, exogenous factors, and poor oral hygiene. ${ }^{4,5}$ In paediatric patients, there has also been a link to genetic syndromes. However, in young adults emphasis on other risk factors in absence of conventional risk factors has been strongly recommended. ${ }^{6-15}$ Human papilloma virus (HPV) has been implicated in the pathogenesis of a subset of oropharyngeal squamous cell carcinoma. ${ }^{16}$ Cancer of the oral cavity is a major public health problem with approximately 300,000 new cases reported annually worldwide. ${ }^{17,18}$ Globally, oral cancer is the sixth most common cause of cancer-related death, although many people are unaware of its existence. ${ }^{19}$ The incidence of oral cancer increases with age in all parts of the world and mainly occurs in the sixth and seventh decade of life, and rare in young adults. ${ }^{20}$ In industrialized countries men are affected two to three times as often as women, largely due to their greater involvement in important risk factors, such as heavy alcohol and tobacco consumption for intra-oral cancer and sun light for lip cancer. ${ }^{19}$ In this study we examined demographic distribution and presence of risk factors in all squamous cell carcinoma cases involving the oral cavity diagnosed at the Regional Cancer Centre, Benghazi, Libya between 1997 and 2007. It was necessary to examine the incidence, distribution, and presence of risk factors in our population where alcohol is prohibited, and no risky behaviours such as betel nut chewing.

\section{Materials and methods}

Records of all patients histologically diagnosed as squamous cell carcinoma of the oral cavity between 1997 and 2007 at Regional Cancer Centre in Benghazi, Libya were retrieved and analysed for gender and age distribution, site of occurrence, and risk factors. Benghazi is the second biggest city and is situated in the eastern part of Libya. The Regional Cancer Centre serves a population of 1.5 million. All pathology cases must be reported at the Regional Cancer Centre either for treatment or for outside referrals. All patients $\leq 40$ years of age were categorised "as young" to make the results comparable with other publications.

\section{Results}

In this study, squamous cell carcinoma lesions comprised $55.2 \%$ of all malignancies involving the oral cavity. The remaining lesions comprised of adenoid cystic carcinoma (18.3\%), mucoepidermoid carcinoma (10.1\%), lymphoma (4.5\%), malignant pleopmorphic adenoma $(4.5 \%)$, malignant melanoma (1.8\%), fibrosarcoma, kaposis sarcoma, acinic cell carcinoma, and embryonic rhabdomyosarcoma. Of the 109 cases, $18(16.5 \%)$ were young ( $\leq 40$ years). Overall male-female ratio was almost 1.9-1. The male- female ratio in patients $\leq 40$ years was $5-1$ and those above 40years old was 1.6-1. Three cases were reported in the paediatric age group (Table 1$)$. The tongue $(66.6 \%)$ was the most common site of OSCC in the young patients. The tongue $(23.0 \%)$ and buccal mucosa $(23.0 \%)$ were the most common sites followed by the maxillary gingiva and alveolar mucosa $(14.28 \%)$ in the patients older 
than 40 years (Table 2). None of the patients suffered from any chronic illness or anaemia and the general health status was found to be satisfactory. Forty two (59.1\%) of the 71 men smoked tobacco, and 5 male patients consumed alcohol. No risk factors were found in female patients. Routine investigations for HPV were not performed during this period.

Table I Age group and gender of patients

\begin{tabular}{|c|c|c|c|}
\hline Age Groups (years) & Male & Female & Total \\
\hline $11-15$ & 1 & 0 & 1 \\
\hline $16-20$ & I & I & 2 \\
\hline $21-25$ & 0 & 0 & 0 \\
\hline $26-30$ & 5 & 0 & 5 \\
\hline $31-35$ & 3 & 0 & 3 \\
\hline $36-40$ & 5 & 2 & 7 \\
\hline $41-45$ & 4 & 3 & 7 \\
\hline $46-50$ & 5 & 4 & 9 \\
\hline $51-55$ & 12 & 7 & 19 \\
\hline $56-60$ & 8 & 6 & 14 \\
\hline $61-65$ & 10 & 3 & 13 \\
\hline $66-70$ & 5 & 4 & 9 \\
\hline 7I-75 & 4 & 3 & 7 \\
\hline $76-80$ & 4 & 2 & 6 \\
\hline $81-85$ & 2 & 2 & 4 \\
\hline $86-90$ & 1 & I & 2 \\
\hline $91-95$ & 1 & 0 & 1 \\
\hline Total (\%) & $7 I(65.1)$ & $38(34.9)$ & $109(100)$ \\
\hline
\end{tabular}

Table 2 Site and age of occurrence

\begin{tabular}{llll}
\hline Site & $<\mathbf{4 0}$ years & $>\mathbf{4 0}$ years & Total \\
\hline Maxillary Gingiva and Alveolar Mucosa I & 13 & 14 \\
$\begin{array}{l}\text { Mandibular Gingiva and Alveolar } \\
\text { Mucosa }\end{array}$ & 0 & 8 & 8 \\
Buccal Mucosa & 3 & 21 & 24 \\
Upper Lip & 0 & 3 & 3 \\
Lower Lip & 0 & 4 & 4 \\
Palate & 0 & 7 & 7 \\
Tongue & 12 & 21 & 33 \\
Floor of the Tooth & 0 & 8 & 8 \\
Retro molar Region & 2 & 6 & 8 \\
Total & 18 & 19 & 109 \\
\hline
\end{tabular}

\section{Discussion}

Squamous cell carcinoma mainly occurs in the sixth and seventh decade of life, and rare in young adults. ${ }^{20}$ The primary reason for occurrence in advanced age is attributed to prolonged exposure to risk factors, mainly alcohol and tobacco,${ }^{13}$ with tobacco smoking being the main risk factor in $41 \%$ of the cases. ${ }^{12}$ In the absence of the main risk factors other etiologic factors such as mouth- washes, viral infections, and syndromes are being evaluated, mainly in younger population where exposure to tobacco and alcohol is less reported. ${ }^{5-15,20}$ We felt the necessity to examine the incidence, distribution, and presence of risk factors in the population where alcohol is prohibited by legislation and religion, and with no risky behaviours such as tobacco and betel nut chewing. In this study, the mean age of occurrence of OSCC in males was 65.4years and in females 54.1years with and age range of 11-94years. Fifty-five (50.4\%) of the 109 cases were reported in the sixth and seventh decade of life, which is similar to most studies reported. Other reports showed relatively low incidence $(0.4-6 \%)^{13,20}$ of OSCC in young adults. However, in our study the incidence was found to be $16.5 \%$, which is in concurrence with the reports from Ibadan and Iran. ${ }^{15,20}$ Squamous cell carcinoma in paediatric patients is extremely rare with a ratio of $1: 1000$ cases or an incidence of $1.1 \% .^{3-15}$ Except for few case reports, there has been no extensive literature in this age group. The risk factors in a paediatric age group are mainly genetically associated syndromes. ${ }^{2,3}$ However, in our study the three cases reported had no associated risk factors. Squamous cell carcinoma of the oral cavity is mainly a disease of men., ${ }^{1,5-15,20}$ Our study reports male predilection in both age groups, with a ratio being higher in patient's $\leq 40$ years. The 5-1 male female ratio reported in young patients is between the ratios 2-1 and 15-1 reported by other studies. ${ }^{12}$ The decrease in ratio with age has been noticed in various studies. Tobacco smoked in the form of cigarettes or hookah (single or multi-stemmed water pipe) was the only risk factor found in 42 (38.5\%) of the 109 patients reported. Three $(20 \%)$ of the 15 male patients under 40 years and $39(68.4 \%)$ of the 57 male patients above 40 years old smoked. None of the female patients in the either age group had risk factors. The role of tobacco is less clear in our patients, similar to studies reported in India and elsewhere. ${ }^{6-8,13}$ The most common site of occurrence was the tongue in young patients, which was also found in other studies. ${ }^{1,2,4,9,10,15,16}$ In our study, the tongue and the buccal mucosa were more commonly involved in patients older than 40. However, other studies reported the tongue and floor of the mouth..$^{5,15}$ In our study, maxillary gingiva was more commonly involved, which was similar to study by Adeyemi et al. ${ }^{15}$ in contrast to mandibular gingiva as reported by other studies. ${ }^{1,5,12}$

\section{Conclusion}

The lack of strong association of traditional risk factors (alcohol and smoking) in our patients, the aetiology in female patients being unclear, and increasing incidence of the tongue as the primary site, we recommend studies that elucidate genetic and viral association with the disease. Our data indicated that ages between 50-65 had a higher incidence of (OSCC) than the other age groups. Preventive measures and awareness campaigns should be arranged by the international agencies and government authorities.

\section{Funding \\ None.}

\section{Acknowledgments}

None.

\section{Conflicts of interest}

The authors declare that there is no conflict of interest. 


\section{References}

1. Ghali GE, Peter EL, Peter DW. Peterson's Principles of Oral and Maxillofacial Surgery. 2nd ed. BC Decker Inc: UK; 2004.

2. Morris LG, Patel SG, Shah JP,et al. Squamous cell carcinoma of the Ora Tongue in the Pediatric Age Group. A Matched-Pair Analysis of Survival. Arch Otolaryngol Head Neck Surg. 2010;136(7):697-701.

3. Sidell D, Nabili V, Lai C, et al. Pediatric squamous cell carcinoma: Case report and literature review. Laryngoscope. 2009;119(8):1538-1541.

4. O Regan EM, Timon C, Sheils O, et al. Squamous cell carcinoma of the head and neck in young Irish adults. Br J Oral Maxillofac Surg. 2006;44(3):203-206.

5. Guha N, Boffetta P, Wünsch Filho V, et al. Oral health and risk of squamous cell carcinoma of the head and neck and esophagus: results of two multicentric case-control studies. Am J Epidemiol. 2007;166(10):11591173.

6. Righini CA, Karkas A, Morel N, et al. Risk factors for cancers of the oral cavity, pharynx (cavity excluded) and larynx. Presse Med. 2008;37(9):1229-1240.

7. Gawecki W, Szyfter K, Szyfter W. The role of exogenous and epidemiological factors in etiology of squamous cell carcinoma of the head and neck in young adults. Otolaryngol Pol. 2007;61(1):52-57.

8. Goldstein DP, Irish JC. Head and neck squamous cell carcinoma in the young patient. Curr Opin Otolaryngol Head Neck Surg. 2005;13(4):207211.

9. Gawecki W, Kostrzewska-Poczekaj M, Gajecka M, et al. The role of genetic factor in etiopathogenesis of squamous cell carcinoma of the head and neck in young adults. Eur Arch Otorhinolaryngol. 2007;264(12):1459-1465.
10. Sherin N, Simi T, Shameena PM, et al. Changing trends in oral cancer. Indian J Cancer. 2008;45(3):93-96.

11. Curado MP, Hashibe M. Recent changes in the epidemiology of head and neck cancer. Curr Opin Oncol. 2009;21(3):194-200.

12. Stewart BW, Kleihues P. World cancer report. IARC Press: France; 2003.

13. Toner M, O'Regan EM. Head and Neck Squamous cell carcinoma in the young: A spectrum or a distinct group? Part 1. Head Neck Pathol. 2009;3(3):246-248.

14. Gupta PC. Mouth cancer in India: a new epidemic? J Indian Med Assoc. 1999;97(9):370-373.

15. Adeyemi BF, Kolude BM, Akang EE. A retrospective histopathological review of oral squamous cell carcinoma in a Nigerian teaching hospital. Afr J Med Med Sci. 2011;40(2):153-158.

16. Woods R, O’Regan EM, Kennedy S, et al. Role of human papilloma virus in oropharyngeal squamous cell carcinoma: A review. World J clin cases. 2014;2(6):172-193.

17. Malik NA. Text book of Oral and Maxillofacial Surgery. 3rd ed. Jaypee Brothers Medical Publishers: UK; 2012.

18. Zhang Y, Wang R, Miao L, et al. Different levels in alcohol and tobacco consumption in head and neck cancer patients from 1957 to 2013. PLoS one. 2015;10(4): $\mathrm{e} 0124045$.

19. Shah JP, Johnson NW, Batsakis JG. Oral Cancer. 1st ed. Martin Dunitz: USA; 2003.

20. Falaki F, Dalirsani Z, Pakfetrat A, et al. Clinical and histopathological analysis of oral squamous cell carcinoma of young patients in Mashhad, Iran: A retrospective study and review of literatures. Med Oral Patol Oral Cir Bucal. 2011;16(4):e473-e477. 